\title{
CRIMINOLOGIA MIDIÁTICA: UM ESTUDO SOBRE O PROGRAMA "CIDADE ALERTA" (REDE RECORD DE TELEVISÃO)
}

\author{
MEDIATIC CRIMINOLOGY: A STUDY CASE ABOUT THE TELEVISION NEWS \\ CHANNEL "CIDADE ALERTA" OF REDE RECORD TV
}

\author{
CRIMINOLOGÍA MEDIÁTICA: UM ESTÚDIO SOBRE EL PROGRAMA “CIDADE \\ ALERTA" (RED RECORD DE TELEVISIÓN)
}

\begin{abstract}
AUGUSTO JOBIM DO AMARAL
https://orcid.org/0000-0003-0874-0583 / http://lattes.cnpq.br/4048832153516187 / guto_jobim@hotmail.com Pontifícia Universidade Católica do Rio Grande do Sul, PUCRS.

Porto Alegre, RS, Brasil.
\end{abstract}

TATIANA das NeVEs SWATEK

http://orcid.org/0000-0001-6447-6065 / http://lattes.cnpq.br/7915778147208772 / tatianaswatek@hotmail.com Pontifícia Universidade Católica do Rio Grande do Sul, PUCRS.

Porto Alegre, RS, Brasil.

\begin{abstract}
RESUMO
O artigo tem como escopo a análise, através da criminologia midiática, das violações de direitos operadas por programas de larga audiência televisiva, com intuito de observar a dramaturgia midiática dirigida por discursos de opinião veiculados por seus "empresários morais". Em televisão aberta, a hipótese que se cumpre afirmar é a notória implicação das práticas de controle penal via uma sociedade da informação. Assim, propõe-se, por meio do exame de telejornal de referência - "Cidade Alerta" (Rede Record de Televisão) -, observar quais as formas de construção de uma realidade social em matéria criminal forjada pela plataforma visual, bem como a grande quantidade de violação de direitos que atingem suspeitos de crimes mediados por este meio de comunicação de massa. Em termos especiais e inéditos, o trabalho verifica empiricamente os impactos da construção social da realidade através da análise pormenorizada de quatro meses do programa (período compreendido entre dezembro de 2017 até março de 2018), tendo como base a classificação de violações midiáticas da plataforma "Mídia sem violações de direitos" do Coletivo "Intervozes". Portanto, ao fim, cruzam-se as informações acerca dos crimes veiculados pelo programa neste intervalo apanhado e as correspondentes violações de direitos cometidas por seus agentes midiáticos.
\end{abstract}

Palavras-chave: Criminologia midiática; Empresários morais; Mídia; Violação de direitos.

\section{ABSTRACT}

The present essay intends to present the mediatic criminology and violation of rights theme, with the purpose of observing the effects of the phenomenon of media manipulation through the opulent discourses given by the moral entrepreneurs in public broadcasting service and also its effects in the information society via criminal control. It is proposed, through the analysis of the television news channel "Cidade Alerta" of Rede Record TV, to observe how the construction of a social reality by this media vehicle in criminal matter takes place through the violation of rights that reach the suspects of crimes reported in these plataforms of communication. Thus, this dissertation intends to verify, empirically, the impacts of the social construction of reality through the detailed analysis of four months of the TV program "Cidade Alerta", in the period comprehended between December 2017 and March 2018, according to the classification of media violations by the Intervozes Collective platform "Media without rights violations" (which carried out the analysis at a national level and in general, based on popular reports), dividing the content analyzed in the program in two: shown crimes and violations of rights committed by the moral entrepreneurs in it.

Keywords: Mediatic criminology; Moral entrepreneur; Media; Violation of rights. 


\section{RESUMEN}

El artículo tiene como objetivo el análisis, a través de la criminología mediática, de las violaciones de derechos operadas por programas de amplia audiencia televisiva, con el propósito de observar la dramaturgia dirigida por discursos de opinión vehiculados por sus "empresarios morales". En televisión abierta, la hipótesis que se cumple es la notoria implicación de las prácticas de control penal vía una sociedad de la información. Así, se propone, por medio del examen de telediario de referencia - "Cidade Alerta" (Red Record de Televisión), observar qué formas de construcción de una realidad social en materia criminal forjada por la plataforma visual, así como la gran cantidad de violación de derechos que afectan a sospechosos de crímenes por este medio de comunicación de masas. En términos especiales e inéditos, el trabajo verifica empíricamente los impactos de la construcción social de la realidad a través del análisis detallado de cuatro meses del programa (período comprendido entre diciembre de 2017 hasta marzo de 2018), teniendo como base la clasificación de violaciones mediáticas de la plataforma "Meios sem violações de direitos" do Coletivo "Intervozes". Por lo tanto, al final, se cruzan las informaciones sobre los crímenes vehiculados por el programa en este intervalo recogido y las correspondientes violaciones de derechos cometidas por sus agentes mediáticos.

Palabras clave: Criminología mediática; Empresarios morales; Medios de comunicación; Violación de derechos.

\section{SUMÁRIO}

INTRODUÇÃO; 1 AS BASES PARA UMA "CRIMINOLOGIA MIDIÁTICA"; 1.1 Sociedade da informação; 2.2 A figura dos "empresários morais"; 2 COMPOSIÇÃO E ANÁLISE DO PROGRAMA "CIDADE ALERTA" DA REDE RECORD DE TELEVISÃO; 2.1 Principais crimes veiculados pelo programa; 2.2 Espécies e principais violações de direitos cometidas no programa Cidade Alerta durante o período de $1^{\circ}$ de dezembro de 2017 a 31 de março de 2018; 2.3 A tentativa de calcular o incalculável; 3 MANIPULAÇÃO MIDIÁTICA; CONCLUSÃO; REFERÊNCIAS.

\section{INTRODUÇÃO}

Da compreensão daquilo que podemos chamar de "criminologia midiática"1 como um campo interdisciplinar acerca da questão criminal, que guarda uma base analítica também desde os papéis sociais forjados e desempenhados pelos meios de comunicação de massa, o presente trabalho pretende interrogar a construção da realidade cotidiana em meio a uma sociedade da informação. Nessa perspectiva, é possível observar que os chamados "empresários morais", apresentadores de programas cuja mensagem-produto é a criminalidade, produzem seus discursos conforme as diretrizes de audiência de cada veículo midiático, em especial, a televisão.

Assim, o tema proposto carrega enorme atualidade e possui profundos reflexos no cotidiano, não apenas nas percepções gerais sobre violência e segurança pública, mas na profusão do sentimento de medo, canalizado como mercadoria a ser vendida - tudo bem amparado desde a visão do poder punitivo como panaceia para todos os males. Sob esse viés, a

1 ZAFFARONI, Eugenio Raúl. La palabra de los muertos: conferencias de criminologia cautelar. Buenos Aires: Ediar, 2011. pp. 365-418. 
presente pesquisa pretende, por meio da análise do telejornal policial “Cidade Alerta" da Rede Record de Televisão, observar o trato midiático em matéria criminal através dos empresários morais, em flagrante violação de direitos e garantias básicas dos suspeitos ali expostos.

Para tanto, foi realizada uma metodologia de revisão bibliográfica em termos de criminologia e sociedade da informação, em especial desde o meio televisivo. A partir disto, parte-se para o estudo de caso no qual foram avaliados 1.019 vídeos de reportagens transmitidas no referido programa, considerando-se o período de quatro meses, de dezembro de 2017 a março de 2018, sobretudo sendo relevados dois aspectos do programa: os crimes por ele veiculados e as respectivas violações de direitos cometidas. 0 instrumento usado para reproduzir a metodologia quantitativa de pesquisa foi retirado da plataforma "Mídia sem violações de direitos" do "Coletivo Intervozes". Assim, por fim, pode-se verificar os impactos da gestão midiático-criminal fomentada pelo Programa de telejornal "Cidade Alerta" em matéria de reprodução de violências e violações de direitos humanos.

\section{AS BASES PARA UMA “CRIMINOLOGIA MIDIÁTICA”}

O campo criminológico sempre foi um espaço de luta entre saberes. Da emergência e consolidação do discurso jurídico-penal moderno, pelo "O Martelo das Bruxas"2 até a atualidade através das discussões travadas pela criminologia pós-crítica, ${ }^{3}$ os teóricos de diversas áreas do conhecimento empenham-se na análise do exercício do poder punitivo sob variadas perspectivas, em geral mais ou menos legitimadoras.

As abordagens criminológicas (as quais aqui não cabe conceituar exaustivamente), não raro, são definições voltadas para os meios acadêmicos. No entanto, criminologia não deve se esgotar nestes meios. Atento a isso, Zaffaroni ${ }^{4}$ prescreve que criminologia também é objeto dos meios comuns da comunicação de massa, através dos discursos proferidos pela mídia. Sem qualquer relação de causalidade estrita, não obstante, constrói-se uma nova criminologia, que se poderia chamar de criminologia midiática.

Nesse sentido, percebe-se que, atualmente, a criminologia midiática não assume compromisso com a fidelidade aos fatos, forjando uma política penal de profundo cariz

2 ZAFFARONI, Eugenio Raúl; BATISTA, Nilo; ALAGIA, Alejandro; SKOLAR, Alejandro. Direito Penal Brasileiro: primeiro volume - Teoria geral do direito penal. 2. ed. Rio de Janeiro: Revan, 2003. pp. 278279.

${ }^{3}$ CARVALHO, Salo de. Antimanual de criminologia. Rio de Janeiro: Lumen Juris, 2008. p. 33.

${ }^{4}$ ZAFFARONI, Eugenio Raúl. La palabra de los muertos: conferencias de criminologia cautelar. Buenos Aires: Ediar, 2011. p. 3. 
punitivo. ${ }^{5}$ Através de uma mídia sensacionalista, que exerce seu poder simbólico, constrói-se uma realidade aceita pelo telespectador e amparada pela disseminação da violência e do medo. ${ }^{6}$

Esse medo disseminado faz com que, por intermédio da criminologia midiática, crie-se uma realidade voltada ao menos a duas figuras centrais, a vítima-herói e o bode expiatório, protótipos do "bem" e "mal", que perduram no discurso midiático como representações de um "nós contra eles". O bode expiatório é o estereótipo dos marginais que necessitam ser neutralizados por serem um símbolo de violência, a ponto de os receptores de mensagem acharem que ele é quem causa todas nossas aflições, não raro jovens negros vulnerabilizados socialmente. ${ }^{7}$ Já a vítima herói seriam os "homens de bem" que foram vítimas de alguma barbárie impetrada por eles. ${ }^{8}$

Cediço que a mídia desempenha um papel importante nas relações sociais, em especial no que tange aos processos de estigmatização e seletividade criminal, impulsionando um controle social altamente discriminatório. Como vetor do poder punitivo, acaba por ser agente de transformação da identidade social daqueles catalogados como população criminosa. ${ }^{9}$ Assim, aquilo que se poderia chamar uma criminologia midiática elabora construções sociais através de meios de comunicação de massa fartamente alimentados por interesses econômicos e políticas de lei e ordem, que transformam o crime e a violência em excelentes mercadorias prontas a circular neste contexto. ${ }^{10}$

\subsection{Sociedade da informação}

Nada novo apontar que, com a globalização dos meios de comunicação, uma dita sociedade da informação ganhou escala mundial, principalmente através da "cibercultura",

${ }^{5}$ BATISTA, Nilo. Mídia e sistema penal no capitalismo tardio. Discursos sediciosos: crime, direito e sociedade, Instituto Carioca de Criminologia. Rio de Janeiro: Revan, ano 7, n. 12, 2002. pp. 271-274.

${ }^{6}$ BOURDIEU, Pierre. Sobre a televisão. Rio de Janeiro: Jorge Zahar Editor, 1997. pp. 24-28.

7 BUDÓ, Marília de Nardin. Mídias e discursos de poder: a legitimação discursiva do encarceramento de adolescentes pobres no Brasil. Tese (doutorado). Programa de Pós-graduação em Direito. Universidade Federal do Paraná, 2013. 310-316. Dp. Disponível em: https: / /acervodigital.ufpr.br/bitstream/handle/1884/34641/R\%20-\%20T\%20-

\%20MARILIA\%20DE\%20NARDIN\%20BUDO.pdf?sequence=1\&isAllowed=y. Acesso em: $12 \mathrm{dez} .2018$.

8 ZAFFARONI, Eugenio Raúl. La palabra de los muertos: conferencias de criminología cautelar. Buenos Aires: Ediar, 2011. p. 194.

9 BARATTA, Alessandro. Criminologia crítica e crítica do direito penal: introdução à sociologia do direito penal. 3. ed. Rio de Janeiro: Revan, 2002. p. 179.

${ }_{10}$ BECKETT, Katherine. Making crime pay: law and order in contemporary american politics. New York: Oxford Press, 1997. pp. 62-78; HALL, Stuart; CRITCHER, Chas; JEFFERSON, Tony; CLARKE, John; ROBERTS, Brian. Policing the crisis: mugging, the state and the law and order. London: Macmillan Press, 1978. pp. 53-80. 
espalhando e ganhando alcance inaudito em até bem pouco tempo. ${ }^{11} \mathrm{Em}$ que pese a possibilidade de acesso a novas tecnologias da comunicação, com a "cooperação e de criação coletiva" da informação no ciberespaço, ${ }^{12}$ isso não elidiu a formação de enormes conglomerados midiáticos, inclusive de internet, que ampliam ademais a possibilidade de tais meios agirem de modo a manipular a informação, sobretudo a fim de que o público a compreenda os dados da maneira que convém ao veículo, principalmente quando o assunto é o cometimento de crimes e seus suspeitos. ${ }^{13}$

A sociedade da informação em dimensão global, principalmente desde a televisão, agora coligada às mídias digitais (celular, computador, tablet etc.), possui um protagonismo inédito em termos criminais. Uma sociedade informatizada, em que as tecnologias de inovação eletrônica dispostas pela rede mundial de computadores são as principais ferramentas, reconfiguram a questão criminal na direção do aprofundamento de suas estratégias de controle, operadas pelas tradicionais práticas seletivas e estigmatizantes.

Ao menos desde a década de 1960, sabe-se o quanto os meios de comunicação de massa são importantes fatores de influência na construção social da realidade, demonstrando-se o quanto veículos midiáticos podem intervir no comportamento humano através da manipulação de informações. ${ }^{14}$ Por sua vez, uma "teoria da comunicação", como em Flusser, ${ }^{15}$ jamais deixou de descrever a sociedade da informação telemática envolvida sob o fenômeno da imagem em movimento (filmes, vídeos, televisão, cinema), e não apenas desde os textos e imagens estáticas.

A proliferação do audiovisual é uma tendência da sociedade da informação e sua característica telemática significa que nela tudo se automatiza a fim de facilitar o reconhecimento da realidade imposta pelas informações. A sociedade da informação se torna, então, uma sociedade uniformizada e tendente ao esvaziamento de significados, quase não havendo espaços para questionamentos mais profundos, visto que seria um empecilho ao curso do consumo de informações. ${ }^{16}$ Assim, o conteúdo se perde e faz com que as tecnologias da informação, para além de uma questão político-econômica, sejam um agudo problema social.

\footnotetext{
11 LÉVY, Pierre. Cibercultura. São Paulo: Editora 34, 1999. p. 111.

12 LÉVY, Pierre. Cibercultura. São Paulo: Editora 34, 1999. p. 199.

${ }^{13}$ FERRELL, Jeff; HAYWARD, Keith; YOUNG, Jock. Cultural Criminology. Londres: SAGE Publications Ltd., 2008. p. 125.

${ }^{14}$ MCLUHAN, Marshall. Os meios de comunicação como extensões do homem. 3. ed. São Paulo: Cultrix, 1971. p. 98.

${ }^{15}$ BERGER, Peter Ludwig; LUCKMANN, Thomas. A construção social da realidade: tratado de sociologia do conhecimento. 21. ed. Petrópolis: Vozes, 2002. pp. 35-37.

${ }^{16}$ HAN, Byung-Chul. Sociedade da transparência. Petrópolis: Vozes, 2017. pp. 10-11.
} 
Se Virilio ressaltava que o "cinema é como um campo de batalha" e os filmes as armas uma guerra simbólica, podemos facilmente transferir tal analogia para a atual forma de exposição das notícias. Somos bombardeados por notícias dos mais diversos teores diariamente que podem, assim como os filmes, entrar "para a categoria das armas a partir do momento em que estão aptos a criar a surpresa técnica ou psicológica" ${ }^{17}$ de enorme impacto na sociedade.

Assim, independente da complexidade que esta aproximação sobre a sociedade da informação demanda, de alguma maneira, cabe destacar o caráter multifacetado da informação e a importância de sua reflexão na atualidade. Propriamente quanto à televisão, o audiovisual movimenta-se conforme o roteiro ou script de quem o escreve e o espetaculariza, modificando a percepção da realidade do telespectador e podendo trazer consequências políticas e econômicas de enorme relevância. ${ }^{18}$

\subsection{A figura dos "empresários morais"}

Quando se discute a manipulação midiática e a própria criminologia midiática, é necessário entender quem são os agentes de criminalização informal que exercem o poder de informar com efeitos quase instantâneos. Para entendermos quem são essas figuras denominadas de "empresários morais" - é necessário identificar os personagens para depois examinar quais suas motivações na veiculação dos conteúdos de determinado modo.

Para Howard Becker, ${ }^{19}$ o empreendedor moral (ou reformador cruzado) é aquele que deseja impor sua própria moral e respeito em face dos outsiders, tendo em vista supostas motivações humanitárias. Já para Stanley Cohen, ${ }^{20}$ os empresários morais são aqueles responsáveis por difundir pânicos morais através dos meios de comunicação de massa. Nessa senda, o autor indica os três papéis importantes da televisão na disseminação dos pânicos morais: estabelecimento de uma ocupação, transmissão de imagens e a reivindicação da solução. Assim, é definido quais são os desvios e problemas sociais, para então, moldar a moral a ser empregada pela população.

\footnotetext{
17 VIRILIO, Paul. Guerra e Cinema. São Paulo: Editora Página Aberta LTDA, 1993. p. 15.

18 BOURDIEU, Pierre. Sobre a televisão. Rio de Janeiro: Jorge Zahar Editor, 1997. pp. 114-116; DEBORD, Guy. A sociedade do espetáculo: seguido do prefácio à $4^{a}$ edição italiana. Rio de Janeiro: Contraponto, 1997, p. 14; ZAFFARONI, Eugenio Raúl. La palabra de los muertos: conferencias de criminología cautelar. Buenos Aires: Ediar, 2011. p. 3.

${ }^{19}$ BECKER, Howard Saul. Outsiders: estudos de sociologia do desvio. Rio de Janeiro: Jorge Zahar Editora, 2008. p. 161.

20 COHEN, Stanley. Folk devils and moral panics: the creation of the Mods and Rockers. London: Routledge, 2011. pp. xxviii-xxix.
} 
Os empresários morais na televisão são, pelo entendimento de Bourdieu, ${ }^{21}$ "pequenos diretores de consciência"; sujeitos hierarquicamente superiores na estrutura social e por isso, protagonistas de um efeito simbólico importante em termos criminais. 0 retrato mais bem acabado disso são os fast thinkers (especialistas de plantão preparados para dizer tudo sobre qualquer coisa mediante ideias pré-aceitas pela sociedade), ${ }^{22}$ sempre em evidência na mídia, que apresentam noticiários e discursam em prol dos interesses dos grupos ou megacorporações que governam a própria emissora e produzem a programação. ${ }^{23}$

A dinâmica trazida por seus conteúdos relaciona-se com a "pressão do campo econômico por intermédio do índice de audiência”. ${ }^{24}$ Sua estruturação se dá pelos interesses conjunturais endereçados à obtenção de maiores fatias de mercado e sucesso comercial; por isso, há uma concorrência entre os programas e os jornalistas para obter o chamado "furo". Assim, produz-se um efeito particular de transformação das produções culturais em produtos comerciais, e a consciência dos telespectadores acaba por ser moldada pelos índices de audiência e forjada pelas relações de poder simbólico exercido em face dos receptores das mensagens. ${ }^{25}$

Diante desse recorte preliminar proposto, faz-se necessário observar como tais estratégias podem ser surpreendidas em "tempo real", sob a égide da interdisciplinaridade criminológica. Para tanto, além de uma inicial reflexão sobre a televisão no Brasil, com os dados próprios em mãos, poderemos adentrar com maior rigor na análise do programa "Cidade Alerta" da Rede Record de Televisão. Ademais, tendo como base a classificação de violações midiáticas desde a plataforma “Mídia sem violações de direitos" do “Coletivo Intervozes", o conteúdo analisado no programa passou a envolver os crimes veiculados e as violações de direitos cometidas por seus “empresários morais".

\section{COMPOSIÇÃO E ANÁLISE DO PROGRAMA “CIDADE ALERTA” DA REDE RECORD DE TELEVISÃO}

\footnotetext{
${ }^{21}$ BOURDIEU, Pierre. Sobre a televisão. Rio de Janeiro: Jorge Zahar Editor, 1997. p. 65.

22 BOURDIEU, Pierre. Sobre a televisão. Rio de Janeiro: Jorge Zahar Editor, 1997. p. 40.

${ }^{23}$ Portanto, os empresários morais podem atuar de diversas formas e tem locais diferentes de fala. Alguns estão em evidência na televisão, a título de exemplificação, apresentadores de programas, comentaristas, especialistas de plantão etc.. Já outros estão exercendo sua influência e manipulando os receptores de mensagem por detrás do palco, ou seja, os escritores, redatores, editores de imagem, entre outros, mas principalmente, os grupos econômicos que têm domínio dos canais de televisão, como referência no Brasil: Grupo Globo, Grupo Silvio Santos, Grupo Record etc. (MEDIA OWNERSHIP MONITOR BRAZIL. Companies database, 2018, Disponível em: http://brazil.mom-rsf.org/en/owners/companies/. Acesso em: 25 mar. 2018).
}

${ }^{24}$ BOURDIEU, Pierre. Sobre a televisão. Rio de Janeiro: Jorge Zahar Editor, 1997. p. 77.

${ }^{25}$ BOURDIEU, Pierre. Sobre a televisão. Rio de Janeiro: Jorge Zahar Editor, 1997. p. 58. 
Como referido, a metodologia da pesquisa foi disposta por uma revisão bibliográfica e de dados audiovisuais, relacionando-os entre si. Diretamente no colhimento dos dados, baseamonos nas diretrizes de Bauer et. al., sendo realizada antes a construção de um corpus ${ }^{26}$ de pesquisa, ou seja, em primeiro plano, dados oficiais de plataformas como "Mídia Dados Brasil”, "Mídia sem Violações de Direitos" e “Mapa da Violência”, entre outros, conjugados, num segundo momento, com o formato audiovisual de vídeo-reportagens, ${ }^{27}$ donde foram extraídos textos empregados nos discursos dos empresários morais.

Consoante os dados da plataforma "Mídia Dados Brasil 2017", há cerca de 68.874.070 domicílios no Brasil, sendo que $97,1 \%$ possuem aparelho televisor nas áreas metropolitanas. ${ }^{28}$ Os brasileiros assistem televisão em média 6 (seis) horas, 11 (onze) minutos e 33 (trinta e três) segundos por dia, ${ }^{29}$ sendo o período de maior acesso entre as 21 (vinte e uma) horas até 22 (vinte e duas) horas. ${ }^{30}$ Logo, boa parte da população brasileira assiste televisão em rede aberta, todos os dias. Atualmente, no país, existem no total, 1.506 emissoras e retransmissoras comerciais de conteúdo, ${ }^{31}$ que são de propriedade dos grupos econômicos e concessionadas pela ANATEL. ${ }^{32}$

${ }^{26}$ I.e., selecionar um tipo ou vários tipos de material (texto, imagem, áudio, etc) para caracterizar o todo (BAUER, Martin W.; GASKELL, George (editores). Pesquisa qualitativa com texto, imagem e som: um manual prático. 2. ed. Petrópolis, RJ: Vozes, 2002. p. 44).

${ }^{27}$ As vídeo-reportagens foram escolhidas diante da dificuldade de encontrar os episódios na íntegra na internet, sendo os vídeos de cada reportagem do dia disponibilizados no banco de dados da página oficial na web do programa Cidade Alerta da Rede Record. Portanto, aduzimos que o levantamento de dados será contabilizado levando em consideração o número de vídeo-reportagens assistidas e não, necessariamente, dos programas na íntegra, já que se tem por base as reportagens nas quais o site permite o acesso, podendo haver outros que não sejam publicados, a fim de resguardá-los ao telespectador ao vivo.

${ }^{28}$ População e domicílios com TV - Áreas metropolitanas (GRUPO DE MÍDIA SÃO PAULO, Mídia Dados Brasil 2017. Disponível em: https://www.gm.org.br/midiadados. Acesso em: 25 mar. 2018).

${ }^{29}$ Média de Tempo do Telespectador considerando as emissoras abertas de televisão e tendo como target da pesquisa o total de indivíduos (GRUPO DE MÍDIA SÃO PAULO, Mídia Dados Brasil 2017. Disponível em: https://www.gm.org.br/midiadados. Acesso em: 25 mar. 2018).

30 De segunda a sexta, 68,98\% dos televisores permanecem ligados. Durante sábado e domingo 64,58\% e $58,13 \%$ dos televisores, respectivamente, nesse horário de maior audiência, estariam ligados, também. Logo, essa porcentagem de população estaria assistindo televisão nos intervalos de tempo referidos. Total de domicílios com televisores ligados (GRUPO DE MÍDIA SÃO PAULO, Mídia Dados Brasil 2017. Disponível em: https://www.gm.org.br/midiadados. Acesso em: 25 mar. 2018).

${ }^{31}$ Número de emissoras comerciais por rede - Geradoras + Retransmissoras (GRUPO DE MÍDIA SÃO PAULO, Mídia Dados Brasil 2017. Disponível em: https://www.gm.org.br/midiadados. Acesso em: 25 mar. 2018).

${ }^{32} \mathrm{Em}$ consulta ao Sistema Interativo da Agência Nacional de Telecomunicações (ANATEL. Consulta geral no Sistema Interativo da ANATEL. Governo Federal do Brasil, 2018. Disponível em: https://sistemas.anatel.gov.br/srd/Consultas/ConsultaGeral/TelaListagem.asp?SISQSmodulo=5243. Acesso em: 23 abr. 2018), é possível verificar o número de emissoras e retransmissoras de cada estado do Brasil, entretanto, não há um resultado contingente nacional indicando, com certeza, quantos canais de televisão existem. 
A partir dessas informações, dentre as principais emissoras de televisão no Brasil, escolheu-se detalhar a composição da programação da Rede Record de Televisão, pois é o canal que dedica a maior porcentagem de sua programação aos gêneros de jornalismo e reportagem. De segunda à sexta, das 7 (sete) horas da manhã às 18 (dezoito) horas da tarde, 40\% da programação é composta por programas de gênero jornalístico; já nos finais de semana (sábado e domingo), no mesmo intervalo de tempo, a ocorrência dos programas de jornalismo sofre uma redução para $25 \%$ da programação total. De segunda a sexta, no período compreendido entre 18 (dezoito) horas e meia-noite, a programação é composta por 29\% de programas em jornalismo; e nos finais de semana, no mesmo período, a incidência dos programas desse gênero na grade é de $24 \% .^{33}$

Em consulta à página oficial na internet da Rede Record de Televisão, o "Portal R7", ${ }^{34}$ na programação semanal, onze são os programas dos gêneros jornalístico e de reportagem televisionados, enquanto novelas e minisséries somam-se cinco; shows e reality shows somam oito e, por fim, na categoria variedades, são apenas quatro programas. Assim, concluiu-se que a emissora tem o maior fornecimento proporcional do formato jornalístico diariamente.

Percebeu-se que dentre os programas de jornalismo e reportagem, o programa "Cidade Alerta" é considerado o carro chefe da Rede Record de Televisão, por conta de seu sucesso comercial e altos índices de audiência. ${ }^{35}$ Além disso, é transmitido nacionalmente, sendo um dos programas de maior duração na grade comparado aos demais na emissora (180 minutos de programação de segunda a sexta e 120 minutos de exibição aos sábados). ${ }^{36}$

${ }^{33}$ Composição da Programação da Rede Record de Televisão (GRUPO DE MÍDIA SÃO PAULO, Mídia Dados Brasil 2017. Disponível em: https://www.gm.org.br/midiadados. Acesso em: 25 mar. 2018).

${ }^{34}$ REDE RECORD. Record TV Programação São Paulo. Disponível em: https: //recordtv.r7.com/programacao. Acesso em: 4 maio 2018.

35 O programa Cidade Alerta tem altos índices de audiência, chegando a apresentar $82 \%$ em audiência em janeiro de 2018, tendo uma média de 9.4 pontos na edição do dia 30 de janeiro de 2018 (MEDEIROS, Lucas. Com Luiz Bacci, Cidade Alerta faz Record disparar 82\% em audiência. O Tv Foco. 2018. Disponível em: https://www.otvfoco.com.br/com-luiz-bacci-cidade-alerta-faz-record-disparar-80-em-audiencia/. Acesso em: 06 mai. 2018) e no mês seguinte, a edição de 14 de fevereiro de 2018 contou com 10,6 pontos na média e 15 pontos de pico (PECCOLI, Vitor. Cidade Alerta bate recorde de audiência em quase um ano. 0 Tv Foco. 2018. Disponível em: https://www.otvfoco.com.br/cidade-alerta-bate-recorde-de-audienciaem-quase-um-ano-confira-os-consolidados-desta-quarta-feira-14-02-18/. Acesso em: 06 maio 2018).

${ }^{36}$ A partir de 29 de janeiro de 2018 o programa passou a ter três horas de duração e a partir desta data, a audiência só aumentou, fechando, em maio de 2018 a maior audiência desde junho de 2012 (SANTANA, André. Record tentou, mas não conseguiu se livrar da dependência do Cidade Alerta. Observatório da Televisão (UOL). 2018. Disponível em: https://observatoriodatelevisao.bol.uol.com.br/critica-detv/2018/01/record-tentou-mas-nao-conseguiu-se-livrar-da-dependencia-do-cidade-alerta. Acesso em: 30 jul. 2018; FALCHETI, Fabrício. Em crescimento, "Cidade Alerta" fecha mês com a maior audiência desde 2012. Na Telinha (UOL). 2018. Disponível em: https://natelinha.uol.com.br/noticias/2018/06/07/em- 
Em suma, o programa destina-se a trazer, em um longo período no ar, diversas reportagens sobre violência urbana e casos criminais, baseadas em boletins de ocorrência policial, ${ }^{37}$ acrescentando a elas comentários de segurança pública, direito e políticas públicas, geralmente pronunciadas por seus apresentadores, personagens emblemáticos e representativos dos ditos empresários morais que comandam o programa - o apresentador Luiz Bacci e o comentarista Percival Souza.

Metodologicamente, como destacado, a observação empírica do telejornal Cidade Alerta da Rede Record de Televisão foi realizada em duas etapas: 1) análise de conteúdo conforme a pesquisa quantitativa e qualitativa do audiovisual e texto, a partir da análise de reportagens em vídeo, transmitidas pelo site oficial do programa Cidade Alerta, e 2) análise de discursos, de maneira a se verificar como ocorre a construção da mensagem em termos criminológicos no programa ${ }^{38}$ e a partir disso, realizar uma crítica com os resultados obtidos.

Para definir a amostragem foi realizado um recorte de quatro meses de programa, referente a $1^{\circ}$ de dezembro de 2017 até 31 de março de 2018, visto que as circunstâncias do caso demandavam um espaço de tempo condizente ao um período em que os altos índices de audiência estivessem presentes. Os vídeos examinados foram exibidos ao vivo no programa, mas retirados do site Cidade Alerta, ${ }^{39}$ e no total foram visualizadas 1.019 reportagens, de, em média, 5 a 7 minutos cada no período fixado.

A criação de um sistema de anotações em tabela foi fundamental para categorizar de forma precisa as duas principais informações retiradas como vetores de análise: os crimes veiculados e as violações de direitos cometidas. Esse recorte já fora disposto, como referido, em pesquisa publicada pelo "Coletivo Intervozes", ${ }^{40}$ e partiu-se das mesmas ferramentas, agora aplicadas ao caso do programa televisivo.

crescimento-cidade-alerta-fecha-mes-com-a-maior-audiencia-desde-2012-117430.php. Acesso em: 30 jul. 2018).

${ }^{37}$ A apuração dos fatos e a transformação do crime em notícia são realizados por seus realizadores de acordo com a perspectiva da vítima, testemunhas, familiares e delegados ou policiais que participam do caso, visto que o programa extrai suas notícias baseadas diretamente em boletins de ocorrência, sequer havendo maior investigação no momento da feitura da reportagem.

${ }_{38}$ GILL, Rosalind. Análise de discurso. In: BAUER, Martin W.; GASKELL, George (editores). Pesquisa qualitativa com texto, imagem e som: um manual prático. 2. ed. Petrópolis, RJ: Editora Vozes, 2002. pp. 249-255.

39 REDE RECORD. Cidade Alerta: vídeos. 2019. Disponível em: https://recordtv.r7.com/cidadealerta/videos. Acesso em: 1 mar. 2019.

40 INTERVOZES Coletivo Brasil e comunicação social. Mídia sem Violações de Direitos. 2015. Disponível em: https://www.midiasemviolacoes.com.br/. Acesso em: 23 abr. 2018. 


\subsection{Principais crimes veiculados pelo programa}

Para que fossem levantados os dados referentes a este subtópico, em um primeiro momento, elaborou-se uma lista com os seguintes ilícitos penais (englobando também aqueles de forma tentada, simples, qualificada etc.): estupro; furto; homicídio; latrocínio; lesão corporal/tentativa de homicídio; roubo; sequestro; tráfico de drogas e outros. ${ }^{41}$

Assim, no período compreendido entre dezembro de 2017 até março de 2018, verificouse que, no total, foram veiculadas 1.019 notícias/reportagens, cada uma contendo um crime, de acordo com a Tabela 1, abaixo reproduzida.

Tabela 1 - Total do levantamento dos crimes veiculados no programa Cidade Alerta no período de dezembro de 2017 até março de 2018

\begin{tabular}{ccccccccccc}
\hline Crime & dez/17 & jan/18 & fev/18 & mar/18 & $\%$ dez & $\%$ jan & $\%$ fev & $\%$ mar & Total & $\%$ \\
\hline Homicídio & 90 & 98 & 103 & 137 & 45,00 & 42,42 & 37,32 & 43,91 & 428 & 42,00 \\
$\quad \begin{array}{c}\text { Outros } \\
\text { Lesão }\end{array}$ & 28 & 45 & 48 & 71 & 14,00 & 19,48 & 17,39 & 22,76 & 192 & 18,84 \\
$\begin{array}{c}\text { corporal/tentativa } \\
\text { de homicídio }\end{array}$ & 31 & 40 & 47 & 45 & 15,50 & 17,32 & 17,03 & 14,42 & 163 & 16,00 \\
$\quad$ Roubo & 15 & 8 & 24 & 18 & 7,50 & 3,46 & 8,70 & 5,77 & 65 & 6,38 \\
Estupro & 11 & 15 & 14 & 15 & 5,50 & 6,49 & 5,07 & 4,81 & 55 & 5,40 \\
Latrocínio & 6 & 9 & 19 & 11 & 3,00 & 3,90 & 6,88 & 3,53 & 45 & 4,42 \\
Tráfico de drogas & 10 & 10 & 15 & 10 & 5,00 & 4,33 & 5,43 & 3,21 & 45 & 4,42 \\
Sequestro & 6 & 3 & 3 & 4 & 3,00 & 1,30 & 1,09 & 1,28 & 16 & 0,98 \\
Furto & 3 & 3 & 3 & 1 & 1,50 & 1,30 & 1,09 & 0,32 & 10 & 0,98 \\
\hline Total & 200 & 231 & 276 & 312 & & & & & 1019 &
\end{tabular}

Fonte: INTERVOZES Coletivo Brasil e comunicação social. Mídia sem Violações de Direitos. 2015. Disponível em: https://www.midiasemviolacoes.com.br/. Acesso em: 23 abr. 2018.

Obteve-se, então, o resultado de que 428 das notícias veicularam crimes relacionados a "homicídio" (contabilizou-se nessa categoria homicídios dolosos, culposos e qualificados, como referido anteriormente), representando $42 \%$ do total supracitado. Depois, em segundo e terceiro lugares, restaram 192 notícias veiculando a categoria “outros" e 163 notícias relacionadas à “lesão corporal/tentativa de homicídios”, representando $18,84 \%$ e $16 \%$ do total,

\footnotetext{
${ }^{41} \mathrm{Em}$ "outros" considerou-se todos os delitos não catalogados anteriormente, como ameaça, cárcere privado, cobertura de ações policiais e do corpo de bombeiros, crimes contra a honra, desaparecimento de menores e adultos, desastres naturais, estelionato, suicídio e outros relacionados ao Código de Defesa do Consumidor e ao Código de Trânsito Brasileiro (salvo se envolvia homicídio e lesão corporal/tentativa de homicídio).
} 
respectivamente. Com relação a "roubo", foram 65 notícias (6,38\%); a "estupro”, 55 notícias (5,40\%); a “latrocínio" e a "tráfico de drogas", 45 notícias, sendo 4,42\% do total para cada; a "sequestro", foram 16 notícias (1,57\%); e, por fim, a "furto", ocorreram 10 notícias $(0,98 \%)$.

Interessa observar que o programa cede mais espaço para crimes extremamente violentos (homicídios e lesão corporal/tentativa de homicídio) com enorme apelo sensacionalista. Em maior parte, são crimes cometidos contra as mulheres por seus companheiros, em razão de violência doméstica.

Também há um profundo contraste entre a realidade e o que é veiculado no programa, expressando a seletividade dos processos de criminalização, especialmente nos crimes contra o patrimônio (furto, roubo etc.), crimes relacionados ao tráfico de drogas e crimes contra a vida (latrocínio, lesão corporal e homicídio em todas as suas formas). Pode-se observar pelos números que a maior parte dos crimes veiculados e explorados são aqueles contra a vida, que chamam mais a atenção e possuem uma dimensão expressiva de acordo com estatísticas do "Mapa da Violência de 2016" e “Atlas da Violência de 2018”. ${ }^{42}$ Mas, em momento algum, há a tentativa séria de apresentar quem de fato são as vítimas destas mortes e por quê.

Doutro modo - se de acordo com o Levantamento Nacional de Informações Penitenciárias (Infopen) -, considerando o número de crimes tentados ou consumados pelos quais as pessoas privadas de liberdade foram condenadas ou aguardam julgamento, ${ }^{43} 37 \%$ foram os crimes contra o patrimônio, $28 \%$ foram crimes da lei de drogas, em terceiro lugar, $11 \%$ foram crimes contra a pessoa, entre outros. ${ }^{44}$ Vê-se em todo esse processo o quanto contribuem os meios de comunicação de massa para forjar a figura estereotipada do criminoso e reproduzir as forças diferenciais com que atuam os processos de criminalização no país, recaindo em regra sobre os mais vulnerabilizados.

\footnotetext{
42 A saber: o número total de homicídios no Brasil em 2014 foi de 44.861, segundo o Mapa da Violência de 2016 (WAISELFISZ, Julio Jacobo. Mapa da Violência 2016: Homicídio por armas de fogo. Brasília: FLACSO, 2016. p. 16. Disponível em: https://www.mapadaviolencia.org.br/pdf2016/Mapa2016_armas_web.pdf. Acesso em: 15 dez. 2018) e em 2016 ocorreram 62.517 homicídios, segundo o Atlas da Violência de 2018 (CERQUEIRA, Daniel (Coord.) et. al. Atlas da Violência 2018. Brasília: Ipea, 2018, p. 20 Disponível em: http://www.ipea.gov.br/portal/images/stories/PDFs/relatorio_institucional/180604_atlas_da_violencia_2 018.pdf. Acesso em: 15 dez. 2018).

${ }^{43}$ Referentes à população prisional do Brasil contabilizada em 726.712 encarcerados até 2016 (BRASIL. Ministério da Justiça e Segurança Pública. Levantamento nacional de informações penitenciárias Infopen - atualização junho de 2016. Brasília: Departamento Penitenciário Nacional, 2017. pp. 41-42. Disponível em: http://depen.gov.br/DEPEN/depen/sisdepen/infopen/relatorio_2016_22-11.pdf. Acesso em: 19 maio 2018).

44 BRASIL. Levantamento nacional de informações penitenciárias Infopen - atualização junho de 2016. p. 43.
} 
São esses processos de criminalização secundária que fazem o poder punitivo selecionar determinados tipos de crimes para serem perseguidos, enquanto outros são sistematicamente esquecidos. ${ }^{45}$ Essa seleção "não só opera sobre os criminalizados, mas também sobre os vitimizados", ${ }^{46}$ pois cediço que a maioria dos homicídios cometidos no Brasil são contra a parcela negra, jovem ${ }^{47}$ e periférica. ${ }^{48} \mathrm{~A}$ abordagem do programa passa longe da real problemática da resolução destes crimes, principalmente quando no país somente $19 \%$ dos inquéritos de homicídio são finalizados, sendo a média nacional de denúncias de $5 \%$ a $8 \% .{ }^{49}$ Todavia, a mídia como um agente de especularização ao atuar acerca de notícias de homicídios não demonstra a realidade dessas vítimas, na medida em que o programa Cidade Alerta expõe, em sua maioria, casos de maior apelo emocional.

Então, em um panorama geral, o programa “Cidade Alerta” tem como objetivo veicular notícias sobre crimes hediondos ou extremamente violentos, sendo a maior parte da programação composta por crimes de homicídio (geralmente feminicídios), lesão corporal/tentativa de homicídio, roubo, estupro (seguido de morte e estupro de vulnerável) e latrocínio. Utiliza-se da tragédia como um produto. Monta-se a imagem de pânico moral relativo à delinquência contra o patrimônio sempre resolúvel com maior repressão. Por conseguinte, a segunda etapa de análise do programa “Cidade Alerta” parte para observar as violações de direitos cometidas midiaticamente.

45 ZAFFARONI, Eugenio Raúl; et al. Direito Penal Brasileiro: primeiro volume - Teoria geral do direito penal. 2. ed. Rio de Janeiro: Revan, 2003. pp. 43-59.

46 ZAFFARONI, Eugenio Raúl; et al. Direito Penal Brasileiro: primeiro volume - Teoria geral do direito penal. 2. ed. Rio de Janeiro: Revan, 2003. pp. 44.

47 Conforme o Atlas da Violência de 2018, até 2016, 94,6\% das vítimas de homicídio por arma de fogo são homens jovens na faixa etária de 15 a 29 anos; 40,2\% das vítimas são negros (pretos e pardos) (CERQUEIRA, Daniel (Coord.) et. al. Atlas da Violência 2018. Brasília: Ipea, 2018, p. 33-43.2 Disponível em:

http://www.ipea.gov.br/portal/images/stories/PDFs/relatorio_institucional/180604_atlas_da_violencia_2 018.pdf. Acesso em: 15 dez. 2018.).

48 BUDÓ, Marília de Nardin. Mídias e discursos de poder: a legitimação discursiva do encarceramento de adolescentes pobres no Brasil, 2013; BUDÓ, Marília de Nardin. Vítimas e monstros: a construção social do adolescente infrator do centro à periferia. Revista Espaço Acadêmico (Universidade Estadual de Maringá), Maringá/PR, v. 15, n. 172. p. 41-52, set. 2015. Disponível em: http://www.periodicos.uem.br/ojs/index.php/EspacoAcademico/article/viewFile/24959/15128. Acesso em: 12 dez. 2018; BUDÓ, Marília de Nardin; CAPPI, Ricardo. Punir os jovens?: a centralidade do castigo nos discursos midiáticos e parlamentares sobre o ato infracional. Belo Horizonte: Letramento, 2018.

${ }^{49}$ CNJ - Conselho Nacional de Justiça. Estratégia Nacional de Justiça e Segurança Pública. Relatório Nacional da Execução da Meta 2: um diagnóstico da investigação de homicídios no país. Brasília, DF: Conselho Nacional do Ministério Público, 2012, p. 43. Disponível em: http://www.cnj.jus.br/images/programas/metas_enasp/relatorio_enasp_web.pdf. Acesso em: 12 dez. 2018 


\subsection{Espécies e principais violações de direitos cometidas no programa Cidade Alerta} durante o período de $1^{\circ}$ de dezembro de 2017 a 31 de março de 2018

Tendo como base a plataforma "Mídia Sem Violações de Direitos", ${ }^{50}$ de forma sucinta, pode-se averiguar como violações de direito, a partir de suas definições correlatas às porcentagens contabilizadas no período estudado: ${ }^{51}$

a) Desrespeito à presunção de inocência

Estando consagrado na Constituição da República Federativa do Brasil (CFRB), em seu artigo $5^{\circ}$, ao inciso $\mathrm{LVII},{ }^{52}$ a presunção de inocência é uma das garantias constitucionais penais de maior relevo, tanto em sede de investigação preliminar quanto no processo penal em si. A presunção de inocência, em sua a dimensão externa, está ligada à estigmatização do réu pela exploração midiática do fato criminoso, vinculando-se às garantias de imagem e dignidade..$^{53}$

Pela plataforma supracitada, o desrespeito à presunção de inocência ocorre quando o comunicador "afirma que determinado indivíduo ou grupo de indivíduos cometeu um crime, com base apenas em boletim de ocorrência policial ou depoimentos de policiais". ${ }^{54} \mathrm{~A}$ simples ação dos "empresários morais", por exemplo, de comunicar o fato criminoso diretamente culpabilizando e julgando previamente os suspeitos, expondo simultaneamente as fotografias, vídeos ou nomes de suspeitos, por exemplo, já configura a violação ao princípio da presunção de inocência.

b) Incitação ao crime e à violência \& incitação à desobediência às leis ou às decisões judiciais

\footnotetext{
50 A plataforma "Mídia Sem Violações de Direitos" (2015) uma campanha de realização do Coletivo “Intervozes” - Coletivo Brasil de Comunicação Social, com apoio da Fundação Rosa Luxemburgo e Andi Comunicação e Direitos, que objetiva monitorar os conteúdos veiculados pela mídia no Brasil, a fim de estimular a população a debater sobre os direitos individuais dos suspeitos de cometerem crimes e acerca dos processos de criminalização inerentes às notícias especulativas e sensacionalistas (INTERVOZES Coletivo Brasil e comunicação social. Mídia sem Violações de Direitos. 2015. Disponível em: https: //www.midiasemviolacoes.com.br/. Acesso em: 23 abr. 2018)

51 Foram consideradas as definições que constam no site da página da plataforma, a estas sendo adicionado o embasamento jurídico pertinente.

${ }^{52}$ Art. $5^{\circ}$, inciso LVII - ninguém será considerado culpado até o trânsito em julgado de sentença penal condenatória (BRASIL. Constituição (1988). Constituição da República Federativa do Brasil de 1988. Brasília, DF: Senado $\quad$ Federal, $1988 . \quad$ Disponível em: http://www.planalto.gov.br/ccivil_03/constituicao/constituicaocompilado.htm. Acesso em: 05 maio 2018).

53 LOPES JUNIOR, Aury. Direito Processual Penal. 14. ed. São Paulo: Saraiva, 2017. p. 95.

${ }^{54}$ INTERVOZES Coletivo Brasil e comunicação social. Mídia sem Violações de Direitos. 2015. Disponível em: https://www.midiasemviolacoes.com.br/. Acesso em: 23 abr. 2018
} 
Essa violação tem lugar quando o interlocutor "se utiliza dos meios de comunicação para incitar outros à prática de um crime ou à desobediência das leis ou decisões judiciais". ${ }^{55}$ Os discursos de desobediência às leis ou decisões raramente atingem alguma legislação individualmente, haja vista que, geralmente, as incitações dirigem-se à ordem jurídica generalizadamente. ${ }^{56} \mathrm{Em}$ se tratando de incitação ao crime, ${ }^{57}$ o empresário moral comete não só a violação midiática, mas também um ilícito penal tipificado no artigo 286 do Código Penal. ${ }^{58}$

c) Exposição indevida de pessoas ou famílias

Esta violação acontece quando o comunicador “expõe a intimidade de uma pessoa, de qualquer idade, sexo ou orientação sexual, vítima ou não de violência(s) física(s), submetendo-a a constrangimento público e expondo-a ao estigma social". ${ }^{59}$ Esse enunciado nos remete à garantia constitucional do direito à vida privada, honra e imagem dos indivíduos, na qual a CRFB assegura direito a indenização pelos danos patrimoniais ou extrapatrimoniais decorrentes de sua violação. ${ }^{60} 61$

Os direitos à honra e imagem estão relacionados à dignidade da pessoa humana e, portanto, o âmbito de proteção desses direitos abrange também "o direito de não ser fotografado ou de ter o seu retrato exposto em público sem o devido consentimento", bem como o de "não ver a imagem pessoal representada e difundida de modo ofensivo ou distorcido". ${ }^{62}{ }^{63} \mathrm{~A}$ exposição indevida de pessoas ou famílias como violação se refere principalmente à privacidade

\footnotetext{
55 INTERVOZES Coletivo Brasil e comunicação social. Mídia sem Violações de Direitos. 2015. Disponível em: https://www.midiasemviolacoes.com.br/. Acesso em: 23 abr. 2018

${ }^{56}$ No sentido de que "as leis não servem para nada, um dia se prende, no outro o juiz solta", "no Brasil deveria ter pena de morte, os bandidos devem morrer" etc.

57 V.g.: dizer, em uma perseguição policial "atira nele, porque ele é bandido", incitando a prática de um homicídio.

${ }^{58}$ Art. 286 do Código Penal - Incitar, publicamente, a prática de crime: Pena - detenção, de três a seis meses, ou multa (BRASIL. Decreto-Lei $n^{\circ}$ 2.848, de 7 de dezembro de 1940. Código Penal. Rio de Janeiro, RJ, 7 dez. 1940. Disponível em: http://www.planalto.gov.br/ccivil_03/decretolei/Del2848compilado.htm. Acesso em: 05 maio 2018).

59 INTERVOZES Coletivo Brasil e comunicação social. Mídia sem Violações de Direitos. 2015. Disponível em: https://www.midiasemviolacoes.com.br/. Acesso em: 23 abr. 2018

${ }^{60}$ Art. $5^{\circ}$, inciso X da CRFB - São invioláveis a intimidade, a vida privada, a honra e a imagem das pessoas, assegurado o direito a indenização pelo dano material ou moral decorrente de sua violação (BRASIL. Constituição (1988). Constituição da República Federativa do Brasil de 1988).

${ }^{61}$ No âmbito do direito internacional, essa garantia é reforçada na Declaração Universal dos Direitos Humanos (10 de dezembro de 1948), na Convenção Europeia de Direitos Humanos (4 de novembro de 1950), no Pacto Internacional sobre Direitos Civis e Políticos (19 de dezembro de 1966) e na Convenção Americana sobre Direitos Humanos - Pacto de São José da Costa Rica (22 de novembro de 1969).

62 SARLET, Ingo Wolfgang; MARINONI, Luiz Guilherme; e MITIDIERO, Daniel. Curso de Direito Constitucional. 6. ed. São Paulo: Saraiva, 2017. p. 481.

${ }^{63}$ Não raro a mídia expõe a intimidade e explora a imagem do bode expiatório, violando sua integridade perante à sociedade, associando-o a um fato criminoso através de depoimentos e fotos.
} 
do indivíduo; ${ }^{64}$ desse modo, cada vez que a mídia expõe indevidamente a imagem de um indivíduo, o privando de sua privacidade e desonrando sua pessoa, já basta para configurar esta violação.

\section{d) Discurso de ódio e preconceito}

A CRFB pretende, em seu bojo, coibir as discriminações arbitrárias para com a origem, raça, sexo, cor, idade, etc. do indivíduo, pois prega em seus artigos iniciais e ao longo da redação o direito de igualdade ${ }^{65}$. Para a doutrina, o direito à igualdade é extremamente complexo, sendo-lhe atribuído dupla dimensão - objetiva e subjetiva - ${ }^{66}$ não cabendo aqui definir todas as nuances e enredamentos, pois trata-se, preliminarmente, de uma análise breve e objetiva do esforço de se delimitar a violação relacionada à discursos de ódio e preconceito. Nesse ínterim, de acordo com a definição do Intervozes, não cabe à mídia e seus operadores - no caso, empresários morais - ofender ou incitar ofensa, discriminação ou prática de violência contra a pessoa ou grupo de pessoas em virtude de qualquer característica cultural, social ou biológica.

e) Identificação de adolescente em conflito com a lei

Aqui se trata do direito de penalmente inimputáveis de acusados de terem cometido ato infracional. Por muitas vezes, a mídia não trata diretamente do nome do adolescente, pois isso é considerada uma infração administrativa, em razão do artigo 247 do Estatuto da Criança e do Adolescente, ${ }^{67}$ todavia a violação se encontra nas menções indiretas. Por mais que não se mencione o nome, apelido ou iniciais do indivíduo, pode-se inferir o reconhecimento do menor

\footnotetext{
${ }^{64}$ SARLET, Ingo Wolfgang; et. al. Curso de Direito Constitucional. 6. ed. São Paulo: Saraiva, 2017. pp. 447-478.

${ }^{65}$ A título exemplificativo: artigos $3^{\circ}$, incisos III e IV; artigo $5^{\circ}$, inciso I; artigo $7^{\circ}$, incisos XXX, XXXI e XXXIV da CRFB (BRASIL. Constituição (1988). Constituição da República Federativa do Brasil de 1988).

${ }^{66}$ SARLET, Ingo Wolfgang; et. al. Curso de Direito Constitucional. 6. ed. São Paulo: Saraiva, 2017. p. 583. ${ }^{67}$ Art. 247 do Estatuto da Criança e do Adolescente. Divulgar, total ou parcialmente, sem autorização devida, por qualquer meio de comunicação, nome, ato ou documento de procedimento policial, administrativo ou judicial relativo a criança ou adolescente a que se atribua ato infracional: Pena - multa de três a vinte salários de referência, aplicando-se o dobro em caso de reincidência. $\$ 1^{\circ}$. Incorre na mesma pena quem exibe, total ou parcialmente, fotografia de criança ou adolescente envolvido em ato infracional, ou qualquer ilustração que the diga respeito ou se refira a atos que the sejam atribuídos, de forma a permitir sua identificação, direta ou indiretamente. $\$ 2^{\circ}$. Se o fato for praticado por órgão de imprensa ou emissora de rádio ou televisão, além da pena prevista neste artigo, a autoridade judiciária poderá determinar a apreensão da publicação. (BRASIL. Lei $n^{\circ} 8.069$ de 13 de julho de 1990. Dispõe sobre o Estatuto da Criança e do Adolescente e dá outras providências. Brasília, DF, 13 jul. 1990. Disponível em: http://www.planalto.gov.br/ccivil_03/leis/L8069Compilado.htm. Acesso em: 05 maio 2018).
} 
através da menção de "filiação, parentesco, residência, ato ou documento de procedimento policial". ${ }^{68}$

Marília Budó et. al. ${ }^{69}$ indica que os discursos apresentados nos veículos de comunicação em torno dos jovens têm como plano de fundo debates parlamentares e midiáticos sobre a redução da maioridade penal e sobre o aumento de prazo de internação. São esses discursos que mantêm as estruturas de poder, violando direitos que acabam por influenciar tanto o controle social informal, que circula na escola, na Igreja, na família e nos meios de comunicação, quanto o controle social formal amparado pelos três Poderes na configuração do sistema penal. ${ }^{70}$ Toda essa mobilização midiática através de discursos punitivistas propaga o desejo pelo encarceramento em massa, especialmente no tocante às crianças e adolescentes que cumprem medidas socioeducativas. ${ }^{71}$

Verifica-se que, independentemente da infração administrativa que as emissoras cometem corriqueiramente (e que não são investigadas), continua-se divulgando fotografias, ilustrações ou dados que permitem identificar, direta ou indiretamente o adolescente em conflito com a lei, pois as funções que a imagem do menor de idade exerce fazem parte do discurso para obter o efeito de definição da criminalidade. ${ }^{72}$

f) Violação do direito ao silêncio, tortura psicológica e tratamento desumano/degradante

O direito ao silêncio, embora seja relacionado ao direito da não-autoincriminação referente ao indiciado ou preso, também deve ser estendido a qualquer pessoa que não esteja submetida, necessariamente à persecução criminal. Isso porque nenhum indivíduo pode ser obrigado por entrevistadores, repórteres e jornalistas (i.e. empresários morais) a ceder um depoimento - seja o suspeito de cometer o ilícito, seja familiares, vizinhos, testemunhas ou até mesmo a vítima.

Ademais, os incisos III e XLIX do artigo $5^{\circ}$ da CRFB asseveram que "ninguém será submetido a tortura, nem a tratamento desumano ou degradante", sendo assegurado o respeito

\footnotetext{
${ }^{68}$ INTERVOZES Coletivo Brasil e comunicação social. Mídia sem Violações de Direitos. 2015. Disponível em: https://www.midiasemviolacoes.com.br/. Acesso em: 23 abr. 2018.

${ }^{69}$ BUDÓ, Marília de Nardin; CAPPI, Ricardo. Punir os jovens?: a centralidade do castigo nos discursos midiáticos e parlamentares sobre o ato infracional. Belo Horizonte: Letramento, 2018.

70 BUDÓ, Marília de Nardin; CAPPI, Ricardo. Punir os jovens?: a centralidade do castigo nos discursos midiáticos e parlamentares sobre o ato infracional. Belo Horizonte: Letramento, 2018. p. 18.

71 BUDÓ, Marília de Nardin; CAPPI, Ricardo. Punir os jovens?: a centralidade do castigo nos discursos midiáticos e parlamentares sobre o ato infracional. Belo Horizonte: Letramento, 2018. p. 20.

72 BUDÓ, Marília de Nardin; et. al.. Punir os jovens?: a centralidade do castigo nos discursos midiáticos e parlamentares sobre o ato infracional. Belo Horizonte: Letramento, 2018. p. 27.
} 
à integridade física e moral. ${ }^{73}$ A tortura psicológica e o tratamento desumano e degradante ofendem à integridade pessoal (física e psíquica) do indivíduo, sendo este o bem jurídico a ser tutelado, não se admitindo ofensa pelo Estado ou terceiros, principalmente quando o indivíduo não permite ou não admite a exposição e a disposição acerca do tratamento sofrido. ${ }^{74}$ Logo, importa destacar que as violações ocorrem quando um empresário moral gera sofrimento mental ao indivíduo entrevistado, coagindo-o, ameaçando-o, submetendo-o a humilhações ou quaisquer tratamentos degradantes.

\subsection{A tentativa de calcular o incalculável}

Novamente, cabe referir que a metodologia utilizada nesta segunda etapa da análise, oportunizou a conceituação e a delimitação do corpus da pesquisa através da análise de conteúdo do discurso e de contexto interpretativo dos vídeos recolhidos, visto como próprios documentos de pesquisa. ${ }^{75}$ Como dito, se a escolha pelo programa se deu por sua notoriedade em virtude dos elevados níveis de audiência, ${ }^{76}$ o recorte analítico teve de passar pelo conteúdo das reportagens e pela estruturação da pauta.

Assim, ao serem analisados 1.019 vídeos, contabilizaram-se um total de 366 violações midiáticas no período compreendido em dezembro de 2017 até março de 2018, em consonância com a Tabela 2, disposta na sequência. Durante um período de menos de 120 (cento e vinte) dias, de acordo com a quantidade auferida, houve mais de 3 (três) violações diárias de direitos.

\footnotetext{
73 Artigo $5^{\circ}$, inciso III, CRFB. Ninguém será submetido a tortura nem a tratamento desumano ou degradante; e Artigo $5^{\circ}$, inciso XLIX, CRFB. É assegurado aos presos o respeito à integridade física e moral. (BRASIL. Constituição (1988). Constituição da República Federativa do Brasil de 1988).

${ }^{74}$ SARLET, Ingo Wolfgang; et. al. Curso de Direito Constitucional. 6. ed. São Paulo: Saraiva, 2017. p. 430.

75 LOIZOS, Peter. Vídeo, filme e fotografias como documentos de pesquisa. In: BAUER, Martin W.; GASKELL, George (editores). Pesquisa qualitativa com texto, imagem e som: um manual prático. 2. ed. Petrópolis, RJ: Vozes, 2002, p. 149; ROSE, Diana. Análise de imagens em movimento. In: BAUER, Martin W.; GASKELL, George (editores). Pesquisa qualitativa com texto, imagem e som: um manual prático. 2. ed. Petrópolis, RJ: Editora Vozes, 2002. p. 346.

76 PECCOLI, Vitor. Cidade Alerta chega a 16 pontos no Ibope e é o programa mais assistido da Record. O TV Foco. 2018. Disponível em: https://www.otvfoco.com.br/cidade-alerta-chega-a-16-pontos-no-ibope-e-eo-programa-mais-assistido-da-record/. Acesso em: 24 ago. 2018.
} 
Tabela 2 - Total de violações midiáticas cometidas no programa Cidade Alerta no período de dezembro de 2017 até março de 2018

\begin{tabular}{ccccccccccc}
\hline Violações & dez/17 & jan/18 & fev/18 & mar/18 & $\%$ dez & $\%$ jan & $\%$ fev & $\%$ mar & Total & $\%$ \\
\hline $\begin{array}{c}\text { Desrespeito à } \\
\text { presunção de }\end{array}$ & 30 & 41 & 29 & 44 & 34,48 & 42,27 & 33,72 & 45,83 & 144 & 39,34 \\
inocência \\
$\begin{array}{c}\text { Tortura psicológica e } \\
\text { tratamento }\end{array}$ & 12 & 15 & 23 & 11 & 13,79 & 15,46 & 26,74 & 11,46 & 61 & 16,67 \\
$\begin{array}{c}\text { desumano/degradante } \\
\text { Exposição indevida de } \\
\text { pessoas/familiares }\end{array}$ & 9 & 10 & 10 & 17 & 10,34 & 10,31 & 11,63 & 17,71 & 46 & 12,57 \\
$\begin{array}{c}\text { Incitação ao } \\
\text { crime/violência }\end{array}$ & 13 & 13 & 6 & 5 & 14,94 & 13,40 & 6,98 & 5,21 & 37 & 10,11 \\
$\begin{array}{c}\text { Incitação à } \\
\text { desobediência às }\end{array}$ & 14 & 7 & 5 & 5 & 16,09 & 7,22 & 5,81 & 5,21 & 31 & 8,47 \\
$\begin{array}{l}\text { leis/decisões judiciais } \\
\text { Discurso de ódio e }\end{array}$ & 6 & 7 & 7 & 3 & 6,90 & 7,22 & 8,14 & 3,13 & 23 & 6,28 \\
$\begin{array}{c}\text { preconceito } \\
\text { Violação do direito ao } \\
\text { silêncio }\end{array}$ & 3 & 3 & 6 & 9 & 3,45 & 3,09 & 6,98 & 9,38 & 21 & 5,74 \\
$\begin{array}{l}\text { Identificação de } \\
\text { adolescente em } \\
\text { conflito com a lei }\end{array}$ & 0 & 1 & 0 & 2 & 0,00 & 1,03 & 0,00 & 2,08 & 3 & 0,82 \\
\hline$\quad$ Total & 87 & 97 & 86 & 96 & & & & & 366 &
\end{tabular}

Fonte: REDE RECORD. Cidade Alerta: vídeos. 2019. Disponível em: <https://recordtv.r7.com/cidadealerta/videos>. Acesso em: 1 mar. 2019.

Discriminando a Tabela 2, observa-se que ocorreram o seguinte número de violações correspondente a cada tipo destas e seu percentual de incidência: 144 incidências de desrespeito à presunção de violência (39,34\%); 61 violações à tortura psicológica e ao tratamento desumano e/ou degradante $(16,67 \%) ; 46$ exposições indevidas de pessoas ou familiares (12,57\%); 37 incitações ao crime ou violência $(10,11 \%) ; 31$ incitações à desobediência às leis ou decisões judiciais (8,47\%); 23 violações por discurso de ódio e preconceito $(6,28 \%) ; 21$ violações do direito ao silêncio (5,74\%); e, por fim, 3 identificações de adolescente em conflito com a lei $(0,82 \%)$. Notou-se, assim, que os comentários, discursos e ações no programa que acarretaram violações de direito transitam, principalmente, sobre as três violações cometidas reiteradamente: desrespeito à presunção de inocência; tortura psicológica e tratamento desumano e/ou degradante; e exposição indevida de pessoas ou familiares.

As principais violações de direito concretizam-se tanto na forma oral quanto na expressão escrita - quando da edição de imagens, com ênfase no discurso proferido pelo apresentador nos títulos das notícias ou pela própria montagem do programa ${ }^{77}$. Tal narrativa

77 É comum a disposição de frases acusando o suspeito e sobrepondo sua imagem. Um discurso inflamado de acusação, sempre de modo a adjetivar o suspeito de "assassino", "bandido", "estuprador", "ladrão", "traficante" etc.. Isto, também, constitui a violação de direito referida. Ademais, mesmo não sendo 
serve para identificar quem são os personagens da história, na qual é atribuído ao suspeito o status de criminoso. Existem poucas condições de qualquer resguardo à presunção de inocência, naturalmente anulada no imaginário do telespectador que acompanha o programa. Com elevados níveis de audiência, há a tendência de uma credibilidade pré-definida, construindo a presunção de culpa.

Toda esta construção imagética de efeitos profundamente concretos e nefastos para as balizas legais podem bem ser registradas em vários momentos. Caso emblemático e ilustrativo das práticas foi aquele registrado pelo apresentador ao expor de forma direta seu desprezo pela presunção de inocência, referindo-se a um homicídio supostamente cometido por homem contra sua ex-mulher:

E é nessa presunção de inocência que muita gente, muitas vezes culpada, vai sendo colocada nas ruas e colocando em risco as famílias das vítimas que foram mortas por eles, não é? Se esse homem, ele realmente matou, ele tem que apodrecer na cadeia, até o último dia dele, tem que ficar atrás das grades. ${ }^{78}$

Frase que inunda e reverbera o senso comum diariamente, inferindo o apresentador que a consequência de "colocar pessoas culpadas na rua" por conta do princípio da presunção de inocência (protegido constitucionalmente) seria "colocar em risco as famílias das vítimas [...] mortas por eles", esperando, sobretudo, que o telespectador concorde com ele através da expressão “não é?". A preocupação do apresentador longe está em apurar o fato, mas sim disseminar ódio e violência com retorno de audiência.

Doutra parte, observa-se que a tortura psicológica e o tratamento desumano/degradante tomam o segundo lugar em frequência de violações cometidas. Consiste na humilhação de suspeitos na frente de outras pessoas (geralmente em reportagens ao vivo), ameaçando-os, coagindo-os ou intimidando-os, a partir de adjetivos degradantes ${ }^{79}$ e obrigandoos a se defender das acusações. A terceira violação midiática mais rotineira é a exposição indevida de pessoas e familiares. Prática que não se importa minimamente em saber do consentimento dos envolvidos com relação à exploração de suas imagens. Produzem-se nos casos em que as vítimas ou familiares estão extremamente abaladas e o repórter insiste na realização

culpado, o suspeito já teve sua integridade violada face à exposição nas televisões de todo o Brasil em um programa sensacionalismo pronto a fixar a identidade de uma pessoa culpada.

78 BACCI, Luiz. Homem não aceita o fim e ataca a ex-mulher. Record R7 Cidade Alerta. 2018, 00:00-

00:16. Disponível em: https://recordtv.r7.com/cidade-alerta/videos/homem-nao-aceita-o-fim-e-ataca-aex-mulher-20102018. Acesso em: 19 maio 2018.

${ }^{79}$ E.g.: "maníaco", "louco", "doente”, "sem escrúpulos”, "sem coração e sem alma”, entre outros. 
das perguntas, quando não ainda na própria situação de funeral. Casos em que a vítima foi violentada sexualmente, a equipe insistia em mostrar sua imagem, revelar onde reside ou ocorreu o fato.

De modo sintético, os dados demonstraram concretamente que não se precisa assistir nem a três notícias veiculadas pelo programa "Cidade Alerta" para que ao menos uma violação de direitos seja cometida. Há que se refletir se, de fato, o sucesso e a audiência do programa não passam além do próprio conteúdo veiculado, mas, sobretudo, através do formato que permite ao apresentador, comentarista e repórteres expressarem sua opinião baseada na mais superficial irresponsabilidade com a concessão pública de comunicação. Diante de tais fatos, cabe algum exercício crítico quanto à performance midiática verificado e como ela é implementada substancialmente a partir da venda do crime como um produto pronto a ser veiculado.

\section{MANIPULAÇÃO MIDIÁTICA}

Bourdieu $^{80}$ refere que a manipulação é um instrumento de mecanismos anônimos para a manutenção da ordem simbólica e tem como efeito a distorção da realidade. Tendo em vista o programa analisado, vê-se, segundo Abramo, ${ }^{81}$ que a manipulação midiática pode ser encontrada através de dois padrões: o padrão de indução e o padrão global de jornalismo televisivo. ${ }^{82}$

O padrão de indução é marcado pela recontextualização da realidade através da edição, corte e recorte de notícias, comentários, dramatização da narração utilizando-se de técnicas especiais de câmera (como proximidade da câmera e foco apenas no apresentador), além da presença ou ausência de determinados temas na programação, de modo que, a partir dessas distorções e reordenamentos, será recriada ficcionalmente uma nova realidade baseada na premissa moral entre o bem e o mal. ${ }^{83}$

\footnotetext{
${ }^{80}$ BOURDIEU, Pierre. Sobre a televisão. Rio de Janeiro: Jorge Zahar Editor, 1997. p. 20.

81 ABRAMO, Perseu. Padrões de manipulação na grande imprensa. 2. ed. São Paulo: Fundação Perseu Abramo, 2016. p. 40.

${ }^{82}$ Existem outros padrões de manipulação, porém os que cabiam referir no programa foram os citados acima. Para maiores informações acerca dos conceitos de padrões de manipulação pelo autor Perseu Abramo, recomenda-se a consulta ao livro "Padrões de manipulação na grande imprensa". 2. ed. São Paulo: Fundação Perseu Abramo, 2016.

83 ABRAMO, Perseu. Padrões de manipulação na grande imprensa. 2. ed. São Paulo: Fundação Perseu Abramo, 2016. p. 50; BERGER, Peter Ludwig; et. al. A construção social da realidade: tratado de sociologia do conhecimento. 21. ed. Petrópolis: Vozes, 2002. pp. 35-37; DEBORD, Guy. A sociedade do espetáculo: seguido do prefácio à $4^{a}$ edição italiana. Rio de Janeiro: Contraponto, 1997. p. 28; FLUSSER,
} 
Já o padrão global do jornalismo da televisão pode ser visto desde três momentos: exposição do fato; sociedade fala; e autoridade resolve ${ }^{84}$. No caso concreto, quando o "Cidade Alerta" expõe o caso, os empresários morais atuam de forma a dramatizar o caso, dicotomizando de um lado o "bode expiatório" e, de outro, a "vítima-herói”, com finalidade de conquistar a audiência pela comoção e mobilização de opiniões. Somado a isso, no segundo e terceiro momentos, também ocorrem entrevistas dos familiares e das autoridades policiais, recorrentes em quase todas as matérias. Isso serve para reforçar dramatização através de familiares e promulgando a resolução do caso desde a imagem da autoridade punitiva.

A seu turno, para que o programa tenha sucesso em seu empreendimento, é necessário que os telespectadores confiem no que está sendo veiculado. Para isso, foram identificados três mecanismos utilizados pelo programa a fim de atingir as massas da melhor maneira possível: a competência discursiva, o discurso sensacionalista e o formato não convencional.

Em primeiro lugar, a competência discursiva de quem está exercendo poder simbólico sobre os telespectadores tem relação com o contexto cultural, social, político e ideológico do país, ou seja, atinge-se a massa de acordo com um discurso local e não globalizado, justamente porque cada comunidade é atingida de modo particular pelo que é veiculado. Em segundo plano, - discurso sensacionalista e violador de direitos que tem como principal característica a ausência de imparcialidade e buscam cativar o telespectador que acaba por reproduzi-lo. Em terceiro lugar, o programa tem um formato não convencional, comparando-se com outros telejornais de referência, visto que não há uma bancada e o apresentador não está sentado atrás dela lendo um teleprompter. 0 apresentador fica em pé todo tempo e, por muitas vezes, ele "foge" do texto original do programa, opinando de "forma livre", fazendo com que ele seja visto como um jornalista "espontâneo". Ademais, o apresentador aproveita e faz um "jogo de câmeras" (que o acompanham em diversos ângulos), trazendo-as para si em diversos momentos, revelando que há uma proximidade com o telespectador, como se estivesse falando diretamente com seu público. Ou seja, há uma interação pretensamente intimista, para que se ganhe confiança e fidelize a audiência.

A alta confiabilidade nas notícias faz com que o crime seja vendido como produto. Como frisa Bourdieu, o efeito real da televisão é “poder fazer ver e fazer crer no que faz ver", tendo como consequência a mobilização, pois ela pode "fazer existir ideias ou representações

Vilém. Filosofia da caixa preta: ensaios para uma futura filosofia da fotografia. Rio de Janeiro: Relume Dumará, 2002. p. 24.

${ }^{84}$ ABRAMO, Perseu. Padrões de manipulação na grande imprensa. 2. ed. São Paulo: Fundação Perseu Abramo, 2016. p. 51. 
[...] carregadas de implicações políticas [...] capazes de desencadear sentimentos fortes”, sendo este o aspecto mais violento do que a própria violência transmitida. ${ }^{85} \mathrm{O}$ efeito final é a pura estigmatização produzida. Arremata-se, assim, que a criminologia midiática, não raro veiculada de modo a manipular sua base informativa, constrói uma realidade própria a amparar o imaginário comum. Sobremaneira, o condicionamento apurado pela televisão, já alertado por Giovanni Sartori, ${ }^{86}$ produz profunda dificuldade em lidar com o pensamento abstrato, dada a profusão de imagens imediatamente expostas, dificuldade esta que acaba por converter o homo sapiens em homo videns.

\section{CONCLUSÃO}

O desenvolvimento do presente estudo possibilitou a análise aprofundada do fenômeno da chamada "criminologia midiática", desde a análise de seus efeitos práticos do telejornal policial "Cidade Alerta" da Rede Record de Televisão, a fim de apurar a construção social da realidade na sociedade da informação através da rotina da violação de direitos veiculados midiaticamente.

A pesquisa teve como foco a atuação dos ditos "empresários morais" no telejornal de referência. Através da seleção e manipulação de imagens e texto, há a naturalização dos crimes num cenário de dicotômico de guerra do bem contra o mal, acabando por dirigir o telespectador brasileiro a anuir na legitimação as violações de direitos. Em suma, foi possível verificar que as violações de direitos estão presentes em $1 / 3$ dos casos analisados, fato que representa os agentes da lei e da ordem como os primeiros a violarem os parâmetros legais.

Dada a importância do assunto, torna-se necessário o desenvolvimento de formas mais eficazes de se identificar as violações de direitos cometidas por estes agentes de criminalização secundária, não apenas em um telejornal de referência, mas de modo global em todas os meios de telecomunicação. Se a mídia de massa pode estar imersa em meios manipulatórios interessados diretamente em ostentar elevados níveis de audiência, não se olvide serem tais veículos concessões públicas que devem respeitar os parâmetros constitucionais.

${ }^{85}$ BOURDIEU, Pierre. Sobre a televisão. Rio de Janeiro: Jorge Zahar Editor, 1997. p. 28.

${ }^{86}$ SARTORI, Giovanni. Homo Videns: televisão e pós-pensamento. Bauru: EDUSC, 2001. cap. 1. pp. 11-38. 


\section{REFERÊNCIAS}

ABRAMO, Perseu. Padrões de manipulação na grande imprensa. 2. ed. São Paulo: Fundação Perseu Abramo, 2016.

ANATEL. Consulta geral no Sistema Interativo da ANATEL. Governo Federal do Brasil. 2018. Disponível em:

https: / / sistemas.anatel.gov.br/srd/Consultas/ConsultaGeral/TelaListagem.asp?SISQSmodulo=52 43. Acesso em: 23 abr. 2018.

BACCI, Luiz. Homem não aceita o fim e ataca a ex-mulher. Record R7 Cidade Alerta. 2018. Disponível em: https: / /recordtv.r7.com/cidade-alerta/videos/homem-nao-aceita-o-fim-e-atacaa-ex-mulher-20102018. Acesso em: 19 maio 2018.

BARATTA, Alessandro. Criminologia crítica e crítica do direito penal: introdução à sociologia do direito penal. 3. ed. Rio de Janeiro: Revan, 2002.

BATISTA, Nilo. Mídia e sistema penal no capitalismo tardio. Discursos sediciosos: crime, direito e sociedade, Instituto Carioca de Criminologia. Rio de Janeiro: Revan, ano 7, n. 12, 2002.

BAUER, Martin W.; GASKELL, George (editores). Pesquisa qualitativa com texto, imagem e som: um manual prático. 2. ed. Petrópolis, RJ: Vozes, 2002.

BECKER, Howard Saul. Outsiders: estudos de sociologia do desvio. Rio de Janeiro: Jorge Zahar Editora, 2008.

BECKETT, Katherine. Making Crime Pay: Law and Order in Contemporary American Politics. New York: Oxford Press, 1997.

BERGER, Peter Ludwig; LUCKMANN, Thomas. A construção social da realidade: tratado de sociologia do conhecimento. 21. ed. Petrópolis: Vozes, 2002.

BOURDIEU, Pierre. Sobre a televisão. Rio de Janeiro: Jorge Zahar Editor, 1997.

BRASIL. Constituição (1988). Constituição da República Federativa do Brasil de 1988. Brasília, DF: Senado Federal, 1988. Disponível em:

http://www.planalto.gov.br/ccivil_03/constituicao/constituicaocompilado.htm. Acesso em: 05 maio 2018.

BRASIL. Decreto-Lei $n^{\circ}$ 2.848, de 7 de dezembro de 1940. Código Penal. Rio de Janeiro, RJ, 7 dez. 1940. Disponível em: http://www.planalto.gov.br/ccivil_03/decreto-

lei/Del2848compilado.htm. Acesso em: 05 maio 2018.

BRASIL. Lei n 8.069 de 13 de julho de 1990. Dispõe sobre o Estatuto da Criança e do Adolescente e dá outras providências. Brasília, DF, 13 jul. 1990. Disponível em:

http://www.planalto.gov.br/ccivil_03/leis/L8069Compilado.htm. Acesso em: 05 maio 2018. 
BRASIL. Ministério da Justiça e Segurança Pública. Levantamento nacional de informações penitenciárias Infopen - atualização junho de 2016. Brasília: Departamento Penitenciário Nacional, 2017. Disponível em:

http://depen.gov.br/DEPEN/depen/sisdepen/infopen/relatorio_2016_22-11.pdf. Acesso em: 19 maio 2018.

BRASIL. Presidência da república. Secretaria Especial de Comunicação Social. Pesquisa brasileira de mídia 2016: hábitos de consumo de mídia pela população brasileira. Brasília: Secom, 2016. Disponível em: http://www.secom.gov.br/atuacao/pesquisa/lista-de-pesquisasquantitativas-e-qualitativas-de-contratos-atuais/pesquisa-brasileira-de-midia-pbm-20161.pdf/view. Acesso em: 05 maio 2018.

BUDÓ, Marília de Nardin. Mídias e discursos de poder: a legitimação discursiva do encarceramento de adolescentes pobres no Brasil. Tese (doutorado). Programa de Pós-graduação em Direito. Universidade Federal do Paraná. 541 f., 2013. Disponível em: https: / /acervodigital.ufpr.br/bitstream/handle/1884/34641/R\%20-\%20T\%20\%20MARILIA\%20DE\%20NARDIN\%20BUDO.pdf?sequence=1\&isAllowed=y. Acesso em: 12 dez. 2018.

BUDÓ, Marília de Nardin. Vítimas e monstros: a construção social do adolescente infrator do centro à periferia. Revista Espaço Acadêmico (Universidade Estadual de Maringá), Maringá/PR, v. 15, n. 172, p. 41-52, set. 2015. Disponível em:

http://www.periodicos.uem.br/ojs/index.php/EspacoAcademico/article/viewFile/24959/15128. Acesso em: 12 dez. 2018.

BUDÓ, Marília de Nardin; CAPPI, Ricardo. Punir os jovens?: a centralidade do castigo nos discursos midiáticos e parlamentares sobre o ato infracional. Belo Horizonte: Letramento, 2018.

CARVALHO, Salo de. Antimanual de criminologia. Rio de Janeiro: Lumen Juris, 2008.

CERQUEIRA, Daniel (Coord.) et. al. Atlas da Violência 2018. Brasília: Ipea, 2018. Disponível em: http://www.ipea.gov.br/portal/images/stories/PDFs/relatorio_institucional/180604_atlas_da_vi olencia_2018.pdf. Acesso em: $15 \mathrm{dez} .2018$.

CNJ - Conselho Nacional de Justiça. Estratégia Nacional de Justiça e Segurança Pública.

Relatório Nacional da Execução da Meta 2: um diagnóstico da investigação de homicídios no país. Brasília, DF: Conselho Nacional do Ministério Público, 2012. Disponível em:

http://www.cnj.jus.br/images/programas/metas_enasp/relatorio_enasp_web.pdf. Acesso em: 12 dez. 2018.

COHEN, Stanley. Folk devils and moral panics: the creation of the Mods and Rockers. London: Routledge, 2011.

DEBORD, Guy. A sociedade do espetáculo: seguido do prefácio à $4^{\mathrm{a}}$ edição italiana. Rio de Janeiro: Contraponto, 1997.

FALCHETI, Fabrício. Em crescimento, "Cidade Alerta" fecha mês com a maior audiência desde 2012. Na Telinha (UOL). 2018. Disponível em:

https: / /natelinha.uol.com.br/noticias/2018/06/07/em-crescimento-cidade-alerta-fecha-mescom-a-maior-audiencia-desde-2012-117430.php. Acesso em: 30 jul. 2018. 
FERRELL, Jeff; HAYWARD, Keith; YOUNG, Jock. Cultural Criminology. Londres: SAGE Publications Ltd., 2008.

FLUSSER, Vilém. Filosofia da caixa preta: ensaios para uma futura filosofia da fotografia. Rio de Janeiro: Relume Dumará, 2002.

GILL, Rosalind. Análise de discurso. In: BAUER, Martin W.; GASKELL, George (editores). Pesquisa qualitativa com texto, imagem e som: um manual prático. 2. ed. Petrópolis, RJ: Editora Vozes, 2002.

GRUPO DE MÍDIA SÃO PAULO. Mídia Dados Brasil 2017. Disponível em: https://www.gm.org.br/midiadados. Acesso em: 25 mar. 2018.

HALL, Stuart; CRITCHER, Chas; JEFFERSON, Tony; CLARKE, John; ROBERTS, Brian. Policing the crisis: mugging, the state and the law and order. London: Macmillan Press, 1978.

HAN, Byung-Chul. Sociedade da transparência. Petrópolis: Vozes, 2017.

INTERVOZES Coletivo Brasil e comunicação social. Mídia sem Violações de Direitos. 2015.

Disponível em: https://www.midiasemviolacoes.com.br/. Acesso em: 23 abr. 2018.

LÉVY, Pierre. Cibercultura. São Paulo: Editora 34, 1999.

LOIZOS, Peter. Vídeo, filme e fotografias como documentos de pesquisa. In: BAUER, Martin W.; GASKELL, George (editores). Pesquisa qualitativa com texto, imagem e som: um manual prático. 2. ed. Petrópolis, RJ: Vozes, 2002.

LOPES JUNIOR, Aury. Direito Processual Penal. 14. ed. São Paulo: Saraiva, 2017.

MCLUHAN, Marshall. Os meios de comunicação como extensões do homem. 3. ed. São Paulo: Cultrix, 1971.

MEDEIROS, Lucas. Com Luiz Bacci, Cidade Alerta faz Record disparar 82\% em audiência. O Tv Foco. 2018. Disponível em: https://www.otvfoco.com.br/com-luiz-bacci-cidade-alerta-fazrecord-disparar-80-em-audiencia/. Acesso em: 06 maio 2018.

MEDIA OWNERSHIP MONITOR BRAZIL. Companies Database. 2018. Disponível em: http://brazil.mom-rsf.org/en/owners/companies/ Acesso em: 25 mar. 2018.

MORIN, Edgar. A cabeça bem feita: repensar a reforma, reformar o pensamento. Rio de Janeiro: Bertrand Brasil, 2000.

PECCOLI, Vitor. Cidade Alerta bate recorde de audiência em quase um ano. O Tv Foco. 2018. Disponível em: https: //www.otvfoco.com.br/cidade-alerta-bate-recorde-de-audiencia-emquase-um-ano-confira-os-consolidados-desta-quarta-feira-14-02-18/. Acesso em: 06 maio 2018.

PECCOLI, Vitor. Cidade Alerta chega a 16 pontos no Ibope e é o programa mais assistido da Record. 0 TV Foco. 2018. Disponível em: https://www.otvfoco.com.br/cidade-alerta-chega-a16-pontos-no-ibope-e-e-o-programa-mais-assistido-da-record/. Acesso em: 24 ago. 2018. 
REDE RECORD. Cidade Alerta: vídeos. 2019. Disponível em: https://recordtv.r7.com/cidadealerta/videos. Acesso em: 1 mar. 2019.

REDE RECORD. Record TV Programação São Paulo. 2018. Disponível em: https://recordtv.r7.com/programacao. Acesso em: 4 maio 2018.

REDE RECORD. Saiba mais sobre o programa Cidade Alerta. 2014. Disponível em: https: / /recordtv.r7.com/cidade-alerta/saiba-mais-sobre-o-programa-cidade-alerta-20102018. Acesso em: 06 mai. 2018.

ROSE, Diana. Análise de imagens em movimento. In: BAUER, Martin W.; GASKELL, George (editores). Pesquisa qualitativa com texto, imagem e som: um manual prático. 2. ed. Petrópolis, RJ: Editora Vozes, 2002.

SANTANA, André. Record tentou, mas não conseguiu se livrar da dependência do Cidade Alerta. Observatório da Televisão (UOL). 2018. Disponível em:

https://observatoriodatelevisao.bol.uol.com.br/critica-de-tv/2018/01/record-tentou-mas-naoconseguiu-se-livrar-da-dependencia-do-cidade-alerta. Acesso em: 30 jul. 2018.

SARLET, Ingo Wolfgang; MARINONI, Luiz Guilherme; e MITIDIERO, Daniel. Curso de Direito Constitucional. 6. ed. São Paulo: Saraiva, 2017.

SARTORI, Giovanni. Homo Videns: televisão e pós-pensamento. Bauru: EDUSC, 2001.

VIRILIO, Paul. Guerra e Cinema. São Paulo: Editora Página Aberta LTDA, 1993.

WAISELFISZ, Julio Jacobo. Mapa da Violência 2016: Homicídio por armas de fogo. Brasília: FLACSO, 2016. Disponível em:

https://www.mapadaviolencia.org.br/pdf2016/Mapa2016_armas_web.pdf. Acesso em: 15 dez. 2018.

ZAFFARONI, Eugenio Raúl. A questão criminal. Rio de Janeiro: Revan, 2013.

ZAFFARONI, Eugenio Raúl. La palabra de los muertos: conferencias de criminología cautelar. Buenos Aires: Ediar, 2011.

ZAFFARONI, Eugenio Raúl; BATISTA, Nilo; ALAGIA, Alejandro; SKOLAR, Alejandro. Direito Penal Brasileiro: primeiro volume - Teoria geral do direito penal. 2. ed. Rio de Janeiro: Revan, 2003. 


\section{COMO FAZER REFERÊNCIA AO ARTIGO (ABNT):}

AMARAL, Augusto Jobim do; SWATEK, Tatiana das Neves. Criminologia midiática: um estudo sobre o programa "Cidade Alerta" (Rede Record de Televisão). Revista Eletrônica do Curso de Direito da UFSM, Santa Maria, RS, v. 15, n. 1, e39072, jan./abr. 2020. ISSN 1981-3694. DOI: http://dx.doi.org/10.5902/1981369439072. Disponível em: https://periodicos.ufsm.br/revistadireito/article/view/39072 Acesso em: dia mês. ano.

Direitos autorais 2020 Revista Eletrônica do Curso de Direito da UFSM

Editores responsáveis: Rafael Santos de Oliveira e Angela Araujo da Silveira Espindola

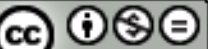

Esta obra está licenciada com uma Licença Creative Commons Atribuição-NãoComercial-SemDerivações 4.0 Internacional.

\section{SOBRE OS AUTORES}

\section{AUGUSTO JOBIM DO AMARAL}

Doutor em Altos Estudos Contemporâneos (Ciência Política, História das Ideias e Estudos Internacionais Comparativos) pela Universidade de Coimbra (Portugal); Doutor, Mestre e Especialista em Ciências Criminais pela Pontifícia Universidade Católica do Rio Grande do Sul (PUCRS). Entre os anos de 2017-2018 realizou estudos de Pós-Doutorado na Universidad de Málaga (UMA/España), na área de "Teoría y Filosofía del Derecho", junto à "Cátedra Abierta de Derecho y Literatura". Entre os anos de 2018-2019 realizou estudos de Pós-Doutorado na Università Degli Studi di Padova/ITA, em Filosofia Política junto ao "Dipartimento di Filosofia, Sociologia, Pedagogia e Psicologia Applicata (FISPPA)", financiado pelo "Coimbra Group Scholarship Programme for Young Professors and Researchers from Latin American Universities?. É Professor do Programa de Pós-Graduação em Ciências Criminais (linha de "Criminologia, Crime e Segurança Pública") e do Programa de Pós-Graduação em Filosofia (linha de "Ética e Filosofia Política"), ambos da Pontifícia Universidade Católica do Rio Grande do Sul (PUCRS). Lidera o Grupo de Pesquisa cadastrado no CNPq "Criminologia, Cultura Punitiva e Crítica Filosófica", tendo experiência na área de Criminologia, Direito, Filosofia Política e História das Ideias, com ênfase em temas como biopolítica, cultura penal, violência punitiva, direitos humanos, controle social e segurança pública; direito penal e processo penal.

\section{TATIANA das NeVES SWATEK}

Possui graduação em Direito pela Pontifícia Universidade Católica do Rio Grande do Sul. Tem experiência na área de Direito, com ênfase em Criminologia. 